\title{
COPPER METABOLISM IN NORMAL ADULTS AND IN CLINICALLY NORMAL RELATIVES OF PATIENTS WITH WILSON'S DISEASE
}

\author{
BY \\ F. C. NEALE AND M. FISCHER-WILLIAMS* \\ From the Queen Elizabeth Hospital, Birmingham
}

(RECEIVED FOR PUBLICATION APRIL 28, 1958)

Wilson's disease (hepato-lenticular degeneration) is now known to be associated with an inborn error of metabolism. The following biochemical abnormalities have been repeatedly confirmed in patients suffering from the disease (Scheinberg, 1956; Bickel, Neale, and Hall, 1957): Increased content of copper in the liver, brain, and other tissues, increased urinary excretion of copper, a decreased level of copper in the serum and an associated decreased level of the copper-containing plasma protein coeruloplasmin. Other biochemical findings include aminoaciduria without necessarily an abnormal level of amino-acids in the blood.

This familial disease is inherited in a recessive, autosomal way (Bearn, 1953). Biochemical abnormalities have occasionally been reported in clinically normal relatives of patients with Wilson's disease, namely an excess amino-aciduria (Uzman and Hood, 1952) and a low coeruloplasmin level (Scheinberg, Dubin, and Harris, 1955). We are not, however, acquainted with any study of the copper metabolism in asymptomatic relatives, and this investigation was therefore undertaken as a further step in the study of this rare but fatal disease.

As a parallel study in order to establish on a comparable basis the normal range of serum copper levels, one of us has examined the blood of 106 normal adults.

\section{Material and Methods}

The serum level and the urinary excretion of copper was estimated in 48 clinically unaffected relatives of cases of hepato-lenticular degeneration. Estimations of coeruloplasmin and urinary amino-acids in the same 48 cases are being carried out by other workers and will be reported later. In all these relatives samples of both blood and urine were

\footnotetext{
*Present address: The London Hospital, Whitechapel, E.1.
}

examined; 39 individuals in one family were investigated and the family tree (Family $A$ ) is shown in Fig. 1. Twenty-three of these were related to the father and 16 to the mother of two patients who died in adolescence of Wilson's disease. Clinical and biochemical studies of these two cases and necropsy findings in one of them have been reported previously (Cases 2 and 8 of Bickel et al., 1957). In addition, the parents and a paternal aunt of two affected siblings in another family (Cases 4 and 11 of Bickel et al.) have been investigated (Family B), also the parents of two other proven cases of the disease (Family C), and the elder brother of two affected siblings (Cases 3 and 7 of Bickel et al., Family D).

The control group of normal persons ranged in age from 16 to 54 years and were all members of the hospital medical and ancillary staff.

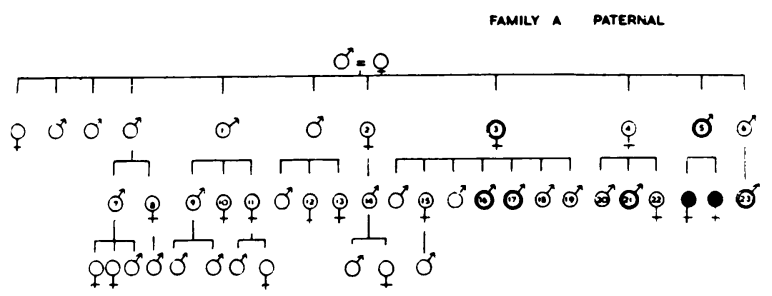

FAMILY A MATERNAL

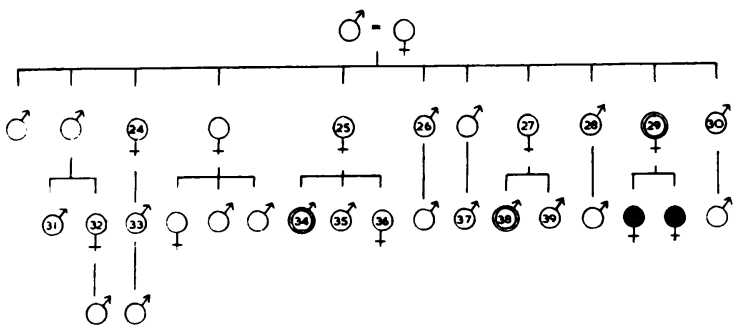

FIG. 1.-Family tree of Family A of whom a total of 39 asymptomatic relatives were investigated. The numbers within the symbols refer to the relatives investigated and can be seen in Table II. $=$ the siblings who died of Wilson's disease. The double circles $i$ dicate the relatives with a low serum copper level (between 47 and $84 \mu \mathrm{g}$. $/ 100 \mathrm{ml}$.). 
Estimation of Copper.-Copper was estimated by a method based on that of Eden and Green (1940) and involves wet ashing of the material. Analyses were carried out in duplicate whenever the sample allowed.

Apparatus.-Special micro-Kjeldahl flasks were made of "pyrex" glass tubing of about $20 \mathrm{~mm}$. outside diameter with bulbs of $35 \mathrm{ml}$. capacity and graduated at $40 \mathrm{ml}$. on the stem. They were 9 in. in length and carried a B19 ground-glass joint at the neck; in these flasks both ashing of the sample and extraction of the copper complex was carried out, avoiding the potential sources of error in transference to other apparatus. The importance of clean glassware and pure chemicals cannot be over-emphasized. The special flasks were cleaned initially by boiling in them a mixture of sulphuric and nitric acids, followed by copious washing with tap- and then glass-distilled water. Other glassware was cleaned with chromic acid, washed out with tap water and thoroughly rinsed with glass-distilled water. Polythene vessels were cleaned with concentrated nitric acid before washing.

Reagents.-Reagents used were AnalaR throughout, this grade being found more suitable than M.A.R. chemicals (giving consistently lower blanks). Ammonium citrate, however, is available only in B.P. quality and contains visible dirt contamination and copper in amounts varying from 0.8 to 4.5 parts per million; it is therefore best prepared from AnalaR citric acid and ammonia $(201.5 \mathrm{~g}$. citric acid monohydrate requires $158.5 \mathrm{ml}$. concentrated ammonia solution to give $250 \mathrm{~g}$. ammonium citrate). The $50 \%$ solution of this reagent so prepared was further purified as follows:

To a $500 \mathrm{ml}$. portion in a separating funnel was added a few millilitres each of concentrated ammonia solution and $2 \%$ aqueous sodium diethyldithiocarbamate. Amyl alcohol was layered on top and, on shaking, copper diethyldithiocarbamate was extracted from the reagent. This process of extraction was repeated until the top layer no longer contained any trace of yellow coloration, and the lower aqueous layer was then suitable for analysis. Several extractions are needed because removal of the copper complex from this very strong salt solution is relatively slow, whereas it is complete in a single extraction from the weaker salt solution resulting from the ashing process.

Procedure for Serum.-Blood, 25-30 ml., was taken directly into "pyrex" centrifuge tubes $(50 \mathrm{ml}$. capacity) through a dry-sterilized needle made from stainless steel tubing without a mount (the mount is omitted because brass is a potential source of copper contamination). The serum was separated within a few hours of collection.

Five millilitres of serum and two small acid-washed glass beads were put into the micro-Kjeldahl flasks. Concentrated sulphuric acid $(2 \mathrm{ml}$.) and nitric acid (1 ml.) were added and the samples ashed in a Kjeldahl-rack until charred, when a little concen- trated nitric acid was added to the flasks (including the blank, consisting only of the acid mixture) until oxidation was complete. Heating must continue for at least an hour after all visible colour has been destroyed in order to avoid yellow-pigmented nitrocompounds when the solution is subsequently made alkaline. Ashing takes two to three hours depending on the amount of organic matter to be destroyed and the frequency of the nitric acid additions. The flasks were allowed to cool, about $5 \mathrm{ml}$. glass-distilled water was added, and the solution reheated till again fuming to remove nitric acid. When once more cool the contents of the flask were diluted with about $20 \mathrm{ml}$. glass-distilled water and $50 \%$ ammonium citrate ( $2 \mathrm{ml}$.) added, followed cautiously with shaking, by concentrated ammonia solution $(10 \mathrm{ml}$.), and, after again cooling, by $2 \%$ aqueous sodium diethyldithiocarbamate $(0.25 \mathrm{ml}$.). Distilled water was added to the $40 \mathrm{ml}$. mark and $5 \mathrm{ml}$. iso-amyl alcohol added: the flasks were closed with glass stoppers and shaken vigorously for one minute. The top layer was allowed to settle and transferred by means of a teat pipette to a dry, clean test-tube, which was then centrifuged to separate possible suspended water droplets. (Centrifugation was preferred to filtration because varying amounts of contaminating material were found to be extracted from different grades of filter paper.)

The extinction coefficients of the clear yellow suluo tions of copper diethyldithiocarbamate were measurecob in a "unicam " quartz spectrophotometer in $1 \mathrm{~cm}$ ? depth at $435 \mathrm{~m} \mu$. Their copper content was obtained by reference to a calibration curve prepared by putting a series of standard solutions containing 0-30 $\mu \mathrm{g}$. copper through the same extraction process. Under conditions in this laboratory $1 \mu \mathrm{g}$. of copper gives an extinction coefficient of 0.044 , and the average copper content of the blank was about two-thirds of a microgram.

Stock Copper Standard Solution.-This contains $100 \mu \mathrm{g} . \mathrm{Cu} / \mathrm{ml}$. and is prepared by dissolving 392.8 mg. $\mathrm{CuSO}_{4} .5 \mathrm{H}_{2} \mathrm{O}$ in 1 litre of distilled water to which a few drops of concentrated sulphuric acid have been added. The stock solution is conveniently diluted 50 -fold $(2 \mu \mathrm{g} . / \mathrm{ml}$.) for preparation of standards for the calibration curve.

Stability of Colour and Its Proportionality to $\frac{D}{0}$ Copper Concentration.-The extinction coefficients of copper diethyldithiocarbamate solutions in amyl $N$ alcohol, prepared as described above, were found to be unchanged after standing overnight at room temperature in glass-stoppered vessels.

Over the concentration range $0-30 \mu \mathrm{g}$. copper the calibration curve was found to be completely linear. Samples of greater copper content may sometimes be encountered when ashing tissues and it was found that no loss in accuracy is occasioned by reading these in cells of shorter path length, e.g., $2 \mathrm{~mm}$. instead of $10 \mathrm{~mm}$., or alternatively, by diluting them with amyl alcohol before reading in the $10 \mathrm{~mm}$. cell, since 
TABLE I

SERUM COPPER LEVELS IN NORMAL CONTROLS

\begin{tabular}{|c|c|c|c|c|c|}
\hline \multicolumn{3}{|c|}{ Male } & \multicolumn{3}{|c|}{ Female } \\
\hline $\begin{array}{c}\text { Control } \\
\text { No. }\end{array}$ & Age & $\begin{array}{c}\text { Copper } \\
\text { Lovel }(\mu \mathrm{g} . \text { ' } \\
100 \mathrm{ml} .)\end{array}$ & $\begin{array}{c}\text { Control } \\
\text { No. }\end{array}$ & Age & $\begin{array}{c}\text { Copper } \\
\text { Level }(\mu \mathrm{g} . / \\
100 \mathrm{ml} .)\end{array}$ \\
\hline $\begin{array}{r}1 \\
2 \\
3 \\
4 \\
5 \\
6 \\
7 \\
8 \\
9 \\
10 \\
11 \\
12 \\
13 \\
14 \\
15 \\
16 \\
17 \\
18 \\
19 \\
20 \\
21 \\
22 \\
23 \\
24 \\
25 \\
26 \\
27 \\
28 \\
29 \\
30 \\
31 \\
32 \\
33 \\
34 \\
35 \\
36 \\
37 \\
38 \\
39 \\
40 \\
41 \\
42 \\
43 \\
44 \\
45 \\
46 \\
47 \\
48 \\
49 \\
50 \\
51 \\
52 \\
53\end{array}$ & $\begin{array}{l}17 \\
17 \\
19 \\
19 \\
19 \\
19 \\
19 \\
20 \\
20 \\
20 \\
20 \\
20 \\
20 \\
20 \\
20 \\
20 \\
20 \\
20 \\
20 \\
20 \\
21 \\
21 \\
21 \\
22 \\
22 \\
22 \\
22 \\
22 \\
23 \\
24 \\
24 \\
24 \\
24 \\
24 \\
24 \\
24 \\
25 \\
25 \\
26 \\
27 \\
28 \\
30 \\
30 \\
31 \\
31 \\
32 \\
35 \\
36 \\
42 \\
46 \\
46 \\
51 \\
54\end{array}$ & $\begin{array}{r}82 \\
83 \\
87 \\
90 \\
94 \\
95 \\
122 \\
94 \\
94 \\
96 \\
98 \\
99 \\
99 \\
103 \\
103 \\
104 \\
104 \\
111 \\
119 \\
124 \\
95 \\
95 \\
99 \\
95 \\
96 \\
99 \\
100 \\
112 \\
91 \\
79 \\
87 \\
95 \\
96 \\
97 \\
99 \\
108 \\
82 \\
97 \\
97 \\
128 \\
131\end{array}$ & $\begin{array}{r}54 \\
55 \\
56 \\
57 \\
58 \\
59 \\
50 \\
61 \\
61 \\
62 \\
63 \\
64 \\
64 \\
65 \\
66 \\
67 \\
68 \\
69 \\
69 \\
70 \\
71 \\
72 \\
73 \\
73 \\
74 \\
75 \\
70\end{array}$ & $\begin{array}{l}16 \\
17 \\
18 \\
18 \\
18 \\
18 \\
18 \\
19 \\
19 \\
20 \\
20 \\
20 \\
20 \\
21 \\
21 \\
21 \\
22 \\
22 \\
22 \\
22 \\
22 \\
23 \\
23 \\
23 \\
23 \\
23 \\
23 \\
23 \\
23\end{array}$ & $\begin{array}{r}113 \\
136 \\
89 \\
96 \\
101 \\
109 \\
136 \\
113 \\
113 \\
91 \\
107 \\
117 \\
125 \\
89 \\
97 \\
119 \\
84 \\
91 \\
99 \\
113 \\
123 \\
95 \\
100 \\
105 \\
110 \\
118 \\
119 \\
125 \\
136 \\
108 \\
110 \\
99 \\
86 \\
70 \\
104 \\
107 \\
118 \\
89 \\
94 \\
106 \\
92 \\
101 \\
113 \\
140 \\
94 \\
123 \\
100 \\
115 \\
128 \\
96 \\
116 \\
124 \\
130\end{array}$ \\
\hline$\underset{53}{\text { Total : }}$ & $\begin{array}{c}\text { Average: } \\
25 \cdot 4\end{array}$ & $\begin{array}{l}\text { Mean } 100 \\
\text { S.D. } \pm 12\end{array}$ & Total: & $\begin{array}{c}\text { Average: } \\
26 \cdot 2\end{array}$ & $\begin{array}{l}\text { Mean } 108 \\
\text { S.D. } \pm 15\end{array}$ \\
\hline Total cases & .. 106 & $\begin{array}{r}\text { Average } \\
\text { age } 25 \cdot 8\end{array}$ & Combine & 1 mean 104 & S.D. \pm 14 \\
\hline
\end{tabular}

equivalent values were obtained if a smaller sample were taken before colour development. This was observed to hold true for samples containing up to $65 \mu \mathrm{g}$. copper.

Reproducibility of Results.-This method has been used during the past seven years, and several hundred duplicate estimations have been performed by one of us (F. N.). The maximum variation between duplicates has been $5 \%$, but the great majority of results have shown an agreement within $3 \%$.

Procedure for Urine.-Urine samples were passed directly into polythene bottles and 24-hour collections were made in almost all cases. Since amino-acids were also to be estimated, $5 \mathrm{ml}$. each of chloroform and glacial acetic acid was used as a preservative. Urinary copper was estimated on samples of the 24hour collection, but, while $10 \mathrm{ml}$. is a suitable quantity from a patient with Wilson's disease, rather more is needed from a normal individual. If the volume of urine is too large, calcium phosphate, which should have been sequestered together with iron by the ammonium citrate, may form a troublesome precipitate. Urine, $20 \mathrm{ml}$., added in two

TABLE II

SERUM COPPER LEVEL AND URINARY COPPER EXCRETION IN 48 ASYMPTOMATIC RELATIVES OF PATIENTS WITH WILSON'S DISEASE

\begin{tabular}{|c|c|c|c|c|c|c|}
\hline \multirow{2}{*}{$\begin{array}{l}\text { Case } \\
\text { No. }\end{array}$} & \multirow{2}{*}{ Sex } & \multirow{2}{*}{ Age } & \multirow{2}{*}{$\begin{array}{c}\text { Serum } \\
\text { Copper } \\
\text { Level } \\
(\mu \mathrm{g} .1 \\
100 \mathrm{ml} .)\end{array}$} & \multicolumn{2}{|c|}{ Urine } & \multirow{2}{*}{$\begin{array}{c}\text { Relationship } \\
\text { to Patient }\end{array}$} \\
\hline & & & & $\underset{\text { (ml.) }}{\text { Volume }}$ & $\left(\begin{array}{c}\text { Copper } \\
(\mu \mathrm{g} . / 24 \mathrm{hr} .)\end{array}\right.$ & \\
\hline $\begin{array}{r}1 \\
2 \\
3 \\
4 \\
5 \\
6 \\
7 \\
8 \\
9 \\
10 \\
11 \\
12 \\
13 \\
14 \\
15 \\
16 \\
17 \\
18 \\
19 \\
20 \\
21 \\
22 \\
23\end{array}$ & $\begin{array}{l}\mathbf{M} \\
\mathbf{F} \\
\mathbf{F} \\
\mathbf{F} \\
\mathbf{M} \\
\mathbf{M} \\
\mathbf{M} \\
\mathbf{F} \\
\mathbf{M} \\
\mathbf{F} \\
\mathbf{F} \\
\mathbf{F} \\
\mathbf{F} \\
\mathbf{M} \\
\mathbf{F} \\
\mathbf{M} \\
\mathbf{M} \\
\mathbf{M} \\
\mathbf{M} \\
\mathbf{M} \\
\mathbf{M} \\
\mathbf{F} \\
\mathbf{M}\end{array}$ & $\begin{array}{l}58 \\
56 \\
54 \\
50 \\
48 \\
45 \\
37 \\
29 \\
30 \\
34 \\
28 \\
27 \\
25 \\
33 \\
31 \\
26 \\
23 \\
18 \\
12 \\
19 \\
13 \\
9 \\
16\end{array}$ & $\begin{array}{l}117 \\
113 \\
82 \\
110 \\
47 \\
100 \\
97 \\
269(1) \\
126 \\
113 \\
96 \\
95 \\
133 \\
91 \\
165(2) \\
71 \\
64 \\
99 \\
112 \\
96 \\
84 \\
103 \\
82\end{array}$ & $\begin{array}{r}620 \\
1,400 \\
1,100 \\
1,350 \\
2,180 \\
1,120 \\
2,380 \\
1,230 \\
1,130 \\
1,500 \\
1,020 \\
1,740 \\
1,460 \\
1,185 \\
1,050 \\
1,050 \\
740 \\
810 \\
1,110 \\
1,130 \\
1,080 \\
1,000 \\
1,410\end{array}$ & $\begin{array}{l}\mathrm{Nil} \\
16 \\
15 \\
18 \\
39 \\
25 \\
\mathrm{Nil} \\
17 \\
7 \\
31 \\
11 \\
\mathrm{Nil} \\
46 \\
17 \\
32 \\
21 \\
22 \\
13 \\
22 \\
15 \\
5 \\
2 \\
6\end{array}$ & 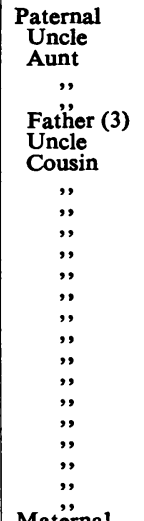 \\
\hline $\begin{array}{l}24 \\
25 \\
26 \\
27 \\
28 \\
29 \\
30 \\
31 \\
32 \\
33 \\
34 \\
35 \\
36 \\
37 \\
38 \\
39 \\
40 \\
41 \\
42 \\
43 \\
44 \\
45 \\
46 \\
47 \\
48\end{array}$ & $\begin{array}{l}\mathbf{F} \\
\mathbf{F} \\
\mathbf{M} \\
\mathbf{F} \\
\mathbf{M} \\
\mathbf{F} \\
\mathbf{M} \\
\mathbf{M} \\
\mathbf{F} \\
\mathbf{M} \\
\mathbf{M} \\
\mathbf{M} \\
\mathbf{F} \\
\mathbf{M} \\
\mathbf{M} \\
\mathbf{M} \\
\mathbf{F} \\
\mathbf{M} \\
\mathbf{F} \\
\mathbf{F} \\
\mathbf{M} \\
\mathbf{F} \\
\mathbf{M} \\
\mathbf{M} \\
\mathbf{M}\end{array}$ & $\begin{array}{l}57 \\
53 \\
48 \\
44 \\
42 \\
41 \\
38 \\
27 \\
25 \\
30 \\
27 \\
22 \\
20 \\
15 \\
15 \\
12 \\
61 \\
63 \\
68 \\
40 \\
42 \\
42 \\
44 \\
21 \\
5\end{array}$ & $\begin{array}{r}109 \\
142 \\
118 \\
112 \\
98 \\
68 \\
109 \\
118 \\
107 \\
132 \\
80 \\
111 \\
112 \\
102 \\
79 \\
108 \\
111 \\
90 \\
127 \\
134 \\
93 \\
147 \\
84 \\
72 \\
131\end{array}$ & $\begin{array}{r}1,940 \\
1,360 \\
1,460 \\
1,410 \\
970 \\
2,570 \\
900 \\
2,230 \\
1,350 \\
1,300 \\
920 \\
1,890 \\
1,370 \\
1,060 \\
1,440 \\
1,240 \\
800 \\
620 \\
1,490 \\
\\
\text { Single } \\
\text { speci- } \\
\text { mens }\end{array}$ & $\begin{array}{c}14 \\
22 \\
20 \\
3 \\
2 \\
46 \\
13 \\
9 \\
34 \\
23 \\
33 \\
15 \\
\mathrm{Nil} \\
12 \\
10 \\
5 \\
25 \\
7 \\
7 \\
\mathrm{Nil} \\
\mathrm{Nil} \\
2 \\
2 \\
4 \\
4\end{array}$ & $\begin{array}{l}\text { Aunt } \\
\text { Uncle } \\
\text { Aunt } \\
\text { Uncle } \\
\text { Mother (3) } \\
\text { Unclo } \\
\text { Cousin } \\
\text {,, } \\
\text {," } \\
\text {,, } \\
\text {," } \\
\text {," } \\
\text { Möher } \\
\text { Fathor } \\
\text { Pat. Aunt } \\
\text { Mother } \\
\text { Father } \\
\text { Mother (3) } \\
\text { Father (3) } \\
\text { Brother (3) } \\
\text { Brother }\end{array}$ \\
\hline & $\begin{array}{l}\text { M } 28 \\
\text { F } 20\end{array}$ & \begin{tabular}{|c|} 
Average \\
29.6 \\
39.7
\end{tabular} & $\begin{array}{l}\text { Mean 97 } \\
\text { S.D. } \pm 20 \\
\text { Mean 112 } \\
\text { S.D. } \pm 19\end{array}$ & & & \\
\hline $\begin{array}{c}\text { Total } \\
48\end{array}$ & & 33.8 & $\begin{array}{l}\text { Mean } 103 \\
\text { S.D. } \pm 21\end{array}$ & & & \\
\hline
\end{tabular}

(1) 3 days post-partum $\}$ Not included in calculation of mean and

(1) 3 months pregnant $\}$ Not inclu

(3) Previously reported (Bickel et al., 1957). 

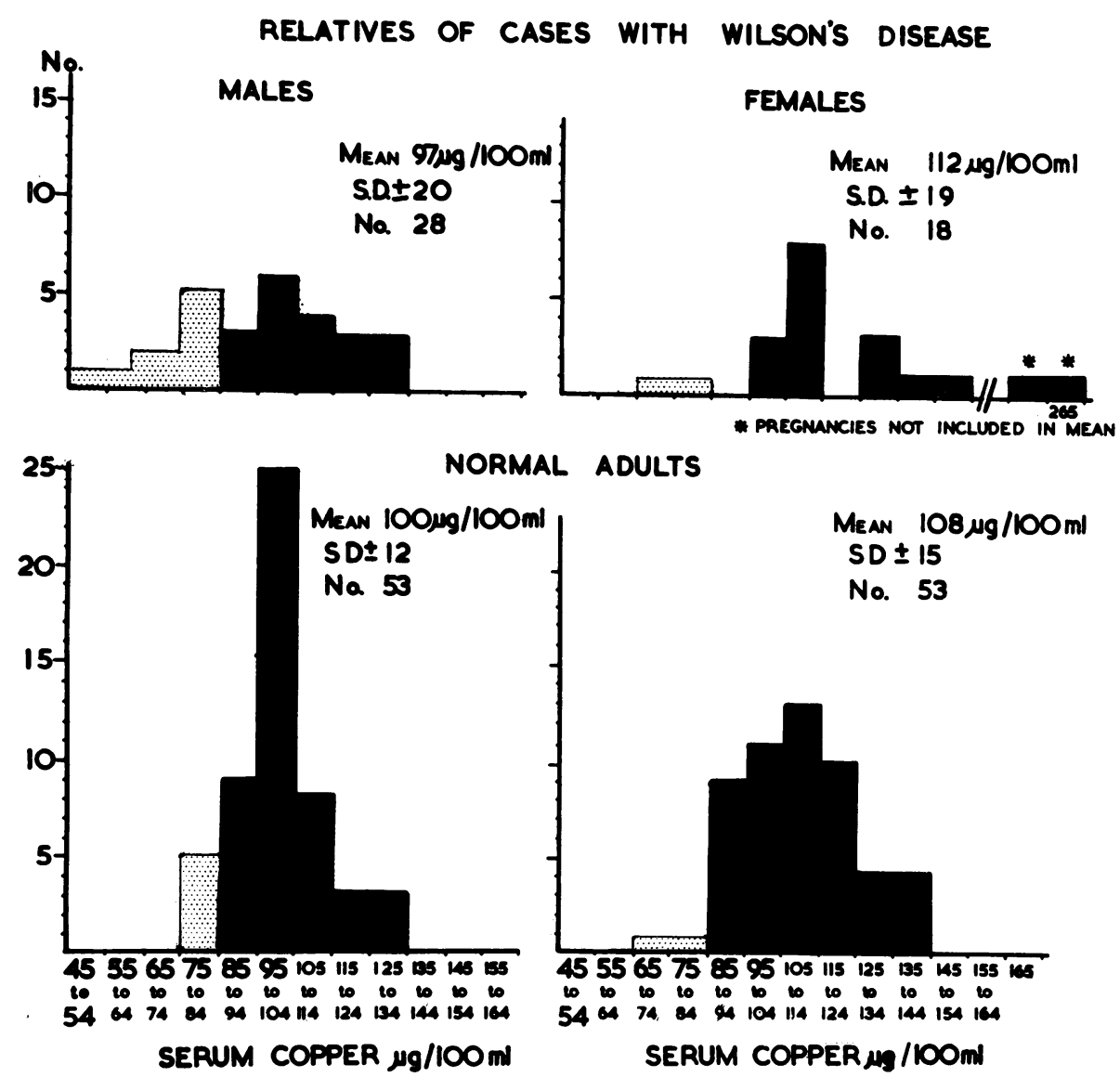

FIG. $2 a$

FIG. 2.-Distribution of serum copper levels in 53 normal males, 53 normal females, and 48 relatives of patients with Wilson's disease. Values below $85 \mu \mathrm{g} .100 \mathrm{ml}$. are shown stippled. In previous studies patients with Wilson's disease were consistently found to have levels between 30 and $70 \mu \mathrm{g} .100 \mathrm{ml}$. The range $70-85$ $\mu \mathrm{g} .100 \mathrm{ml}$. is here considered "low normal." A high proportion of these male relatives have a low or "low normal" serum copper level. Nine out of the 28 male relatives have a level below $85 \mu \mathrm{g} .100 \mathrm{ml}$. as compared with five out of 53 in the control group.

portions of $10 \mathrm{ml}$., is an adequate sample and guards against occlusion or adsorption losses; the procedure thereafter is as described for serum.

\section{Results}

Serum Copper Levels in Normal Controls.The serum copper levels found in 53 normal males (average age 25.4) and 53 normal females (average age 26.2) are given in Table I and Fig. 2. The male values range from 76 to $133 \mu \mathrm{g}$. per $100 \mathrm{ml}$. with a mean of 100 and a standard deviation of $\pm 12 \mu \mathrm{g}$. per $100 \mathrm{ml}$. The female values range from 70 to $140 \mu \mathrm{g}$. per $100 \mathrm{ml}$., with a mean of 108 and a standard deviation of $\pm 15 \mu \mathrm{g}$. per 100 $\mathrm{ml}$. The difference, $8 \mu \mathrm{g}$. per $100 \mathrm{ml}$, , between these means is found to be significant $(P<0.01)$.
Serum Copper Levels in Relatives of Patients. The serum copper levels in the 48 clinically healthy relatives are shown in Table II and Fig. 2.

The relatives are numbered 1 to 39 as indicated in the trees of family A. Numbers 40 to 48 inclusive refer to the three other pairs of parents, one paternal aunt and two siblings.

Of these 48 individuals, 11 have a low or normal level (below $85 \mu \mathrm{g}$. $/ 100 \mathrm{ml}$.). Two of these are the father and brother (aged 21) of two siblings who died of Wilson's disease. The other nine with low levels $(47-84 \mu \mathrm{g}$. $/ 100 \mathrm{ml}$.) are all members of one family (family A) of whom a total of 39 asymptomatic relatives were examined. These nine relatives include both parents of the two sisters who died of Wilson's disease, their paternal 

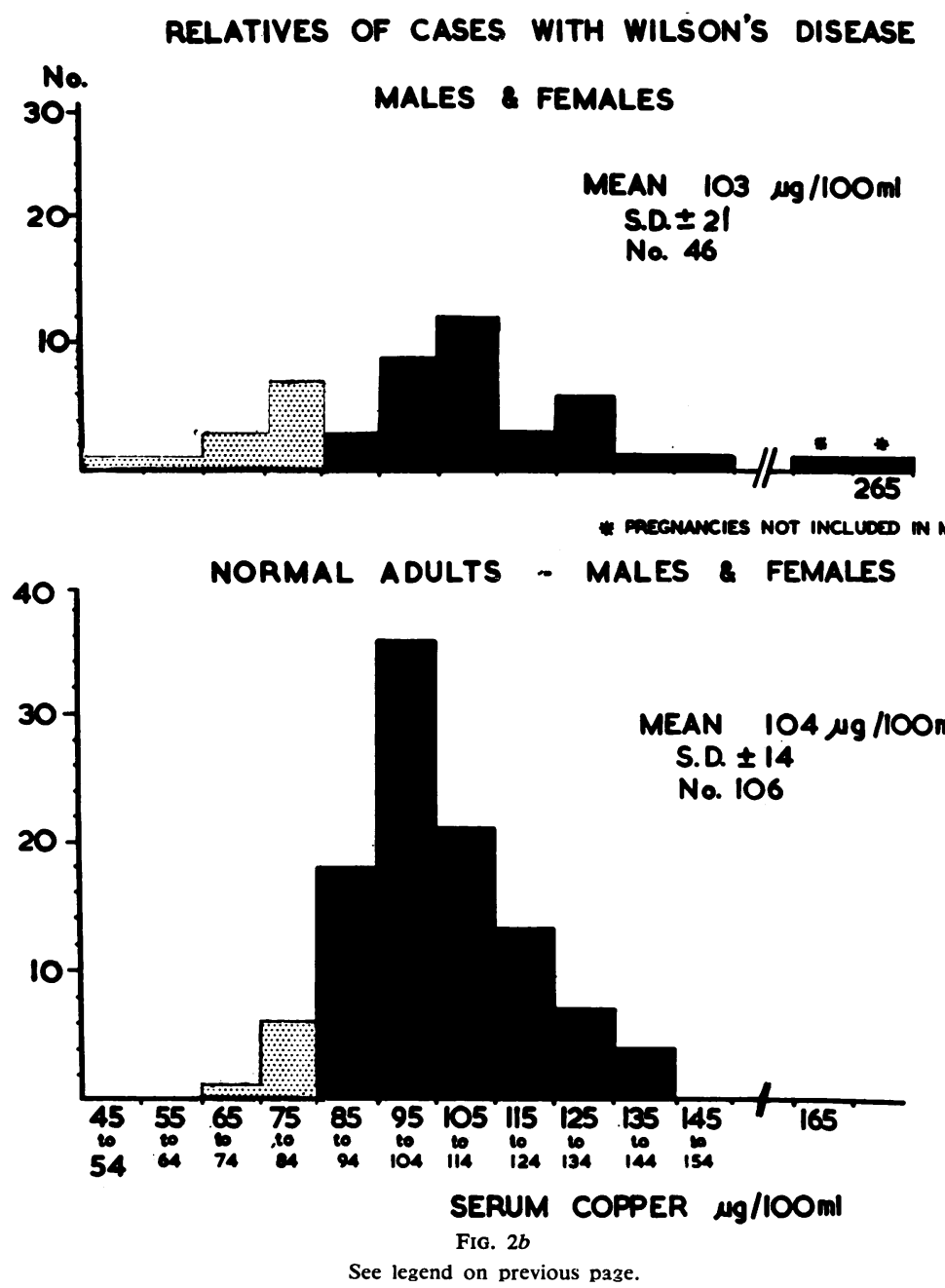

aunt, and two of her sons aged 26 and 23, and four other cousins all male (two paternal aged 13 and 16 and two maternal aged 27 and 15).

These low or low-normal copper levels were not found as a "pure streak" in the family. The four male cousins with low levels all respectively had parents with normal copper values. The paternal aunt who had two sons with low levels had two other boys with values well within the normal range. The father was also investigated, as an " internal control," to exclude environmental factors and his values were normal (serum copper $120 \mu \mathrm{g} . / 100 \mathrm{ml}$., urinary copper excretion 34 $\mu \mathrm{g} . / 24 \mathrm{hr}$.).

The abnormally high values found in two relatives were associated with childbearing; No. 15 was three months pregnant and No. 8 had been delivered three days before examination.
The remaining relatives (namely, 35 individuals) have serum copper levels between 90 and $147 \mu \mathrm{g}$./ $100 \mathrm{ml}$. which falls within our normal range.

Urinary Copper Excretion.-None of the relatives was found to excrete more than $50 \mu \mathrm{g}$. copper per 24 hours, the values ranging from nil to $46 \mu \mathrm{g}$.

Among 14 cases of Wilson's disease investigated personally, the copper excretion was always high, commonly $200-800 \mu \mathrm{g}$. $/ 24 \mathrm{hr}$. in untreated patients, and the lowest value recorded for 24 hours was $100 \mu \mathrm{g}$.

The urinary copper excretion in these relatives was therefore normal and well below the pathological level.

\section{Clinico-pathological Data}

The first cousin of the mother of the two sisters with Wilson's disease in family $\mathbf{A}$ had almost cer- 
tainly died from hepato-lenticular degeneration. She had dysphagia and difficulty in walking, and in 1938, when attending the West End Hospital for Nervous Diseases under the care of Dr. Colin Edwards, she showed a "Parkinsonian" mask, mild rigidity with loss of associated movements, and coarse tremor and incoordination of the limbs, particularly the right. She became emaciated and died aged 33. Necropsy performed at the West Middlesex Hospital (P.M. No. 455.38) showed a small nodular liver with advanced cirrhosis and splenomegaly, the spleen being four to five times the normal size, with increased fibrous tissue. There is no record of examination of the brain.

Other deaths in the families confirmed by necropsy had been due to alcoholic delirium tremens (one case), coronary thrombosis (one case), and rheumatic endocarditis (one case).

A medical history was obtained and brief medical examination carried out by one of us on the relatives numbered 1-42 inclusive. A familial incidence of gall-bladder disease (three out of 11 siblings, seven of whom were examined) was found in family A, but this was not considered of significance. A male relative (No. 41) had albuminuria and had been diagnosed the previous month as being in the non-oedematous stage of the nephrotic syndrome. A decreased level of serum copper has been reported in some cases of the nephrotic syndrome (Cartwright, Gubler, and Wintrobe, 1954), but this patient's serum copper concentration was normal $(98 \mu \mathrm{g} . / 100 \mathrm{ml}$.).

One member (No. 6) suffered from verified ulcerative colitis. No other significant illness was detected.

Bearn (1953) has shown that the incidence of first and second cousin marriages is higher in Wilson's disease than is usually recorded for conditions with recessive inheritance. A high incidence of cousin marriages might reveal other rare recessive abnormalities. In one of our families (Family B) two brothers had married two sisters but there was no known consanguinity.

\section{Discussion}

Several points of interest arise out of this study of the copper metabolism of 48 clinically normal relatives of patients with Wilson's disease. First, the serum copper levels in parents of proven cases may be normal or abnormal. Bearn (1953) states that in no parents "available for study was any biochemical abnormality found," but he does not quote the number of cases examined or the copper levels found. Out of the eight parents (four pairs), two (one pair) had abnormally low serum copper levels, the remaining six (three pairs) all being normal (see Table II). Secondly, the criteria for the diagnosis of Wilson's disease need to be considered. Scheinberg (1956) states that "a finding of a level of coeruloplasmin below about $15 \mathrm{mg}$./ $100 \mathrm{ml}$. of plasma, in a subject who is not newly born and is not suffering from the nephrotic syndrome, is probably a sufficient criterion for the diagnosis of Wilson's disease." This cannot be true of the father of one of the proven cases. His serum copper level on three separate occasions over the past 18 months has been 47,45 , and 48 $\mu \mathrm{g}$. $/ 100 \mathrm{ml}$. respectively. Since $95 \%$ of the copper in the serum is firmly bound in coeruloplasmin (Holmberg and Laurell, 1951) and since normally there is $25 \mathrm{mg}$. of coeruloplasmin per $100 \mathrm{ml}$. of plasma (Scheinberg and Gitlin, 1952), it is clear that this man has a level of coeruloplasmin well below $15 \mathrm{mg}$. $/ 100 \mathrm{ml}$. of plasma and yet he is clinically healthy in every respect.

The factors which may influence the serum copper levels have not yet been fully elucidated. Although the level has been found to be relatively steady in both the normal and the abnormal (particularly in the abnormal), some normal controls show unexpected fluctuations. For example, a healthy woman aged 27 (control No. 87) had a level of $70 \mu \mathrm{g} . / 100 \mathrm{ml}$. (duplicates 69 and 71 $\mu \mathrm{g} . / 100 \mathrm{ml}$.) on the first examination, but on five subsequent occasions she was found to have levels ranging from 84 to $91 \mu \mathrm{g} . / 100 \mathrm{ml}$. The problem of this fluctuation in normal subjects is at present being studied and the results will be published later.

It has been demonstrated that there is a statistically significant sex difference in that the level is higher in females, which is in accordance with the findings of previous workers in Scandinavia and America (Lahey, Gubler, Cartwright, and Wintrobe, 1953). This higher serum copper level in females may be associated with the higher levels of circulating oestrogens, and the wider range with fluctuating levels of oestrogens. Since the group under discussion mainly included young adults the data cannot be used to correlate possible changes with age. Cartwright et al. (1954) in 228 normal adults found that the mean for serum copper was $116 \pm$ S.D. $14 \mu \mathrm{g} . / 100 \mathrm{ml}$. Only 10 of his subjects $(4.4 \%)$ had a value of less than $90 \mu \mathrm{g} . / 100 \mathrm{ml}$.

The occasional low serum copper found in normal relatives of patients with Wilson's disease may be a biochemical abnormality preceding overt clinical manifestations. Alternatively it 
may be consistent with a normal span of healthy life. In the latter case it could still represent a hereditary flaw capable of producing disease in a suitably constituted offspring. Since six of the cases are aged 26 to 54 and show no signs of developing hepato-lenticular degeneration, it is most unlikely that biochemical abnormality in their case is going to herald clinical disease. The five others are aged 13-23 and, theoretically, therefore it is possible (although unlikely) that they are candidates for the illness.

In order to decide whether the low serum copper level was fortuitous and unconnected with Wilson's disease or, as seems more likely, of some significance in the inheritance of the disease, it would be interesting to study copper tissue levels in these relatives, but for obvious reasons this is not possible.

Although numbers are small, it may be significant that the low serum copper levels in the relatives were found more frequently amongst the males than the females (see Fig. 2).

Abnormal amino-aciduria was found in five asymptomatic siblings of a family in which four siblings had died of Wilson's disease (Uzman and Hood, 1952). However, Bearn and Kunkel (1954) did not find any excess amino-aciduria in 35 individuals whose siblings suffered from the clinical disease. The present study of copper metabolism in 41 members of the same family shows that this inborn error of metabolism is expressed relatively rarely as a biochemical abnormality dissociated from clinical disease.

\section{Summary}

A biochemical study has been undertaken on 48 clinically normal relatives of patients suffering from Wilson's disease.
The copper values obtained in serum and urine in these 48 individuals is reported together with a control study of 106 normal adults.

The urinary copper excretion was normal in all the relatives.

The mean value for serum copper has been found to be $100 \mu \mathrm{g} . / 100 \mathrm{ml}$. in normal males and $108 \mu \mathrm{g} . / 100 \mathrm{ml}$. in normal females, and this sex difference is statistically significant.

Interpreted in the light of these control values, 35 out of 48 relatives show normal serum copper levels.

Two child-bearing relatives show high values.

The parents of cases of Wilson's disease may be biochemically normal or abnormal.

Eleven asymptomatic relatives showed low serum copper levels and five of these were undoubtedly abnormal (47-70 $\mu \mathrm{g}$. $/ 100 \mathrm{ml}$.).

Since half of these relatives were beyond the age at which Wilson's disease manifests itself it may be concluded that some unaffected relatives have abnormally low serum copper levels.

We would like to thank Dr. Gilbert Hall for his interest in this study. We also thank all those who co-operated by giving samples of blood, and Drs. G. M. Aber, S. Horner, and E. Price, who obtained the samples from the controls. We are also grateful to Professor Penrose and Dr. Eliot Slater for their interest in the genetical aspects of the work.

\section{REFERENCES}

Bearn, A. G. (1953). Amer. J. Med., 15, 442

and Kunkel, H. G. (1954). J. clin. Invest., 33, 400.

Bickel, H., Neale, F. C., and Hall, G. (1957). Quart. J. Med., $26,527$. Cartwright, G. E., Gubler, C. J., and Wintrobe, M. M. (1954). J. clin. Invest., 33, 685.

Eden, A., and Green, H. H. (1940). Biochem. J., 34, 1202.

Holmberg, C. G., and Laurell, C. B. (1951). Scand. J. clin. Lab. Invest., 3, 103.

Lahey, M. E., Gubler, C. J., Cartwright, G. E., and Wintrobe, M. M. (1953). J. clin. Invest., 32, 322.

Scheinberg, H. (1956). In Neurochemistry, p. 52, ed. S. R. Korey and J. I. Nurnberger. Cassell, London. and Gitlin, D. (1952). Science, 116, 484.

- Dubin, D. T., and Harris, R.S. (1955). J. clin. Invest ., 34, 961

Uzman, L. L., and Hood, B. (1952). Amer. J. med. Sci., 223, 392. 